\title{
Ensaio: da história às características do gênero na esfera literária
}

\author{
Neluana Leuz de Oliveira FERRAGINI CORREIO*
}

\begin{abstract}
* Professora Adjunta na Universidade Estadual do Paraná (UNESPAR - campus Apucarana), com atuação no curso de Letras-Português. Mestrado (2011) e Doutorado (2015) em Estudos da Linguagem pela Universidade Estadual de Londrina. Contato: nelu_oliveira@hotmail.com.
\end{abstract}

\begin{abstract}
Resumo:
O gênero ensaio corresponde a uma modalidade discursiva com contornos maleáveis que pode circular em diferenciadas esferas da comunicação humana. No domínio literário, o ensaio combina conceitos e juízos, figuras e metáforas, críticas e análises. Trata-se de uma reflexão discursiva, cultivada por um processo de subjetivação artística cujo produto resulta em profunda contemplação de um tema e/ou análise de uma obra, período, estilo. Não obstante seja reconhecido como gênero argumentativo, ao ensaio como produção literária não se destinam maiores e mais detalhados estudos quanto às suas características. Dessa forma, a presente abordagem propõe-se a apresentar uma categorização para o gênero, ancorada na perspectiva bakhtiniana de gêneros discursivos, ao observar as marcas linguístico-enunciativas, condições de produção, conteúdo temático e construção composicional. Para empreender a compilação de corpus para análise, deriva-se, metodologicamente, das seguintes etapas: i) investigação de textos-enunciados/obras que se intitulassem ensaio(s) e/ou abordassem o enunciado ensaio; ii) diagnóstico e apreciação do material; iii) seleção e estudo de textos representativos do gênero; iv) organização das características do ensaio na esfera literária. Nessa perspectiva, discorre-se sobre a genealogia do ensaio e apresenta-se uma organização para as regularidades e instabilidades do gênero a partir dos textos-enunciados analisados.
\end{abstract}

\section{Palavras-chave:}

Gêneros discursivos. Ensaio literário. Categorização.

Signum: Estudos da Linguagem, Londrina, v. 21, n. 3, p. 288-307, dez. 2018 


\section{Ensaio: da história às características do gênero na esfera literária}

Neluana Leuz de Oliveira Ferragini Correio

\section{INTRODUÇão}

No ensino e na aprendizagem de português, os enunciados concretos dos gêneros discursivos são caminhos de ascensão ao letramento, pois, ao refletirem as produções encontradas em nosso cotidiano, demandam compreensão quanto aos objetivos enunciativos, organizações e estilos alcançados concretamente por meio das condições sociais, históricas, institucionais, tecnológicas e ideológicas. Compreendidos dessa forma, os gêneros, conjunto de enunciados relativamente estáveis (BAKHTIN, 2003) podem ser meios de transformação social e formas de se explorar e enriquecer possibilidades comunicativas. Afinal, é na produção de enunciados e através deles, que (re)produzimos práticas sociais.

Apesar da relativa estabilidade, Bakhtin (2003) aponta três elementos que se encontram interligados no enunciado e intrinsecamente relacionados ao contexto sóciohistórico: conteúdo temático, construção composicional e estilo.

O contexto compreende o ambiente de criação do enunciado, são as condições reais que determinam a enunciação. Envolve fatores constituintes do discurso e suas representações, como: a relação autor/enunciador e interlocutor/enunciatário e o lugar (papel) social que assumem no momento da interação; como também a imagem que o autor tem de seu interlocutor, como o enunciador representa para si o outro com quem procura interagir ${ }^{1}$; a finalidade discursiva, ou seja, o objetivo que o produtor intenta alcançar ao interagir com o interlocutor, considerando o papel que assumem em determinado contexto; a época e o local de enunciação/publicação e de circulação do enunciado, já que os fatores sociais e históricos motivam e interferem na produção enunciativa, determinando, por exemplo, escolhas composicionais, textuais, sintáticas, lexicais etc. Além dos elementos elencados, o contexto insere-se em um campo/esfera/domínio discursivo, o qual, por sua vez, pode propiciar suportes próprios. O suporte consiste no meio físico ou virtual para criação e divulgação de um enunciado, podendo, muitas vezes, determinar ${ }^{2}$ o gênero.

\footnotetext{
${ }^{1}$ Bakhtin (2003, p. 301) lembra que a representação do outro, feita pelo enunciador e a influência que este tem sobre o enunciado determinam a composição e, de modo particular, o estilo do enunciado.

${ }^{2} \mathrm{O}$ local de publicação/circulação de enunciado é determinante, muitas vezes, para nomear um enunciado. Por exemplo: "Preciso falar urgente com você, entre em contato comigo assim que puder, Joana"; escrito em um pequeno pedaço de papel, pode ser um bilhete; enviado pelo celular, um MSN; deixado na secretária eletrônica, um recado.
} 
O conteúdo temático não corresponde ao assunto a ser abordado; todavia, abarca dessemelhantes atribuições de sentidos e seus admissíveis recortes para um gênero do discurso específico. Para Bakhtin (2003), o tema é o objeto de sentido, ideologicamente conformado, segundo pontua Rojo (2005) e, assim, avaliativa e interacionalmente construído entre os interlocutores (PERFEITO, 2012).

Intensamente relacionado ao tema aparece o estilo. Para Bakhtin e Volochinov (2004, p. 144), o estilo organiza, à sua maneira, os discursos do outro e os elementos da língua, não negando, dessa forma, o caráter individual do autor, porém, nunca deixa de ser visto como um fenômeno social, uma vez que ele sempre se relaciona com os enunciados alheios. Assim, para os pesquisadores, todo estilo está ligado ao gênero, mas pode refletir a individualidade do enunciador, isto é, o estilo pessoal. Nesse sentido, ao selecionar e combinar determinados gêneros do discurso de acordo com os campos de atividades em que são realizados, o sujeito escolhe também os recursos textuais, lexicais e gramaticais. E, por meio de sua expressividade, retoma e modifica o que já fora expresso a respeito do tema.

Consoante o dito, o estilo é uma das marcas que caracterizam o gênero, bem como as escolhas do enunciador. Por isso, para aludir ao estilo próprio do gênero discursivo, denominamos marcas-linguísticas, que se configuram como os elementos representativos, tais como a escolha verbal. Para representar as marcas que caracterizam o estilo do autor, referimo-nos a elas como marcas-enunciativas, que são as escolhas feitas pelo autor, mas não obrigatoriamente marcas do gênero, como um discurso mais conciso, destaque de palavras (negrito, caixa alta, sublinhado ou itálico), notas, enfim, marcas que definem a particularidade de escritura de um enunciador.

A construção composicional diz respeito às formas de organização do enunciado, sendo artifícios que remetem à sua estruturação e ao seu acabamento. Pode referir-se tanto ao aspecto visual como também às formas de escritura. Em outras palavras, a "imagem” do texto-enunciado, muitas vezes, determina o gênero apenas com uma rápida observação do arranjo espacial e seu suporte, como quando olhamos, por exemplo, a estrutura de uma carta, de um anúncio publicitário, de um bilhete colocado na geladeira, dos versos de um poema. Nesses casos, antes mesmo de lermos, já conseguimos ter uma ideia de que se trata de uma carta, de um anúncio, de um bilhete e de um poema.

Entendemos que os enunciados - socialmente produzidos - devem ser estudados / analisados a partir das esferas de atividades em que são produzidos, das relações dialógicas que estabelecem, das escolhas linguísticas feitas pelo emissor - fruto de seu objetivo, do interlocutor com o qual busca interagir, do suporte do texto, do conteúdo temático, os quais são determinados pelos parâmetros da situação de produção dos enunciados e, sobretudo, conforme salientam Bakhtin/Volochinov (2004), pela apreciação valorativa do locutor no que tange ao tema e ao(s) interlocutor(es) de seu discurso.

Nessa perspectiva, o trabalho em tela apresenta uma proposta, a partir da análise dialógica do discurso (BAKHTIN, 2003), considerando o estudo particular de textos-enunciado do gênero ensaio, produzidos e com circulação no domínio literário, ao 
qual chamamos de ensaios literários. O objetivo é organizar uma categorização para o gênero discursivo ensaio na esfera literária, ao buscar responder à seguinte indagação: o que é um ensaio e como se constitui como gênero discursivo na esfera literária?

Justificamos a seleção do ensaio literário por duas razões: em primeiro lugar, motivados pela enigmática forma discursiva que refletem os enunciados sob a forma de ensaio; misterioso discurso, sem formas rígidas, de contornos flexíveis, capaz de discorrer sobre inúmeros temas, nas mais variadas esferas. A segunda razão remete à ausência de estudos que contemplem as características do gênero. Destarte, corresponde a uma modalidade discursiva pouco versada pela esfera acadêmico-científica brasileira, embora produzida por consagrados nomes da literatura nacional.

Para compreender melhor as marcas do gênero ensaio, discorremos, na seção seguinte, sobre o contexto sócio-histórico que originou sua criação.

\section{A Genealogia do Ensaio como Gênero Discursivo}

Michel de Montaigne é considerado o "criador" do gênero, por ser o primeiro a nomear um conjunto de textos como ensaio. A maioria dos críticos o considera o pai do ensaio já que, em 1580, publica uma coletânea de textos - redigidos em tom coloquial - à qual intitula Essais. Na obra, pode-se observar "a gestação progressiva de um novo tipo de comunicação literária”, como postula Cruz (1997, p. 50, tradução nossa).

Em contrapartida, Moisés (2007), não obstante também aponte Montaigne como criador do gênero, assinala que o francês foi precedido por Plutarco, denominando-o "patriarca dos ensaístas". Para o estudioso, de certa forma, Montaigne também foi precedido por Aristóteles, Platão, Marco Aurélio e outros, como ainda pela copiosa "literatura de adágios, exemplos, apotegmas, em circulação no decurso do século XVI” (MOISÉS, 2007, p. 72).

García Gual (1991) é outro pesquisador que acredita na influência de Plutarco na produção ensaística de Montaigne. Para o referido estudioso, a reflexão moral e o tom coloquial dos escritos do francês são resgatados da produção cínica e estoica de Sêneca e Plutarco, pensadores que o influenciaram durante o Renascimento.

Do mesmo modo, Soares (2006) salienta que, embora Montaigne seja considerado o pai do ensaio, uma vez que foi o primeiro a conceituá-lo e a empregá-lo para intitular sua obra, a Antiguidade registra grandes ensaístas, os quais perpassam, ainda na atualidade, as matrizes do pensamento ocidental. Os textos clássicos, de certo modo, parecem ter contribuído para o desenvolvimento do gênero em estudo. Todavia, convém lembrar que o período em que surge a obra Essais corresponde, literariamente, ao Renascimento ${ }^{3}$.

\footnotetext{
${ }^{3}$ É importante relembrar que, em alguns manuais de literatura, o termo Renascimento também é sinônimo de Classicismo. Como no Classicismo/Renascimento, no Barroco e no Neoclassicismo também houve o culto de escritores "clássicos", optamos por Renascimento.
} 
A sociedade renascença (final do século XV e século XVI) caracteriza-se, em especial, pela "revelação de uma realidade que se faz à luz sobretudo do raciocínio. O clássico gosta de raciocinar, para compreender [...] Os escritores são intelectuais, melhor diríamos, intelectualizados" (PROENÇA FILHO, 1985, p. 129). É o período em que o conhecimento científico - explicado teórica e comprovadamente - assume posição de prestígio diante de explicações religiosas.

Historicamente, corresponde ao contexto das grandes conquistas marítimas e ao contato mercantil com a Ásia, o que amplia o comércio e enriquece comerciantes, os quais passam a financiar produções artísticas. No cenário cultural, o período é marcado pela descoberta da tipografia em meados do século XV, acelerando "prodigiosamente a difusão das idéias e das notícias, e constituiu-se em poderoso factor de transmissão ideológica" (SARAIVA; LOPES, 1997, p. 171). Diante do desbravamento além-mar, o velho mundo descobre um mundo novo. Os descobrimentos transoceânicos alargam a geografia do pretérito. A civilização renascentista torna-se essencialmente marítima e o espírito de expansão domina o homem da época. O homem redescobre-se, é aventureiro, desbravador e curioso.

$\mathrm{O}$ nascimento do gênero ensaio decorre justamente do novo espírito que move o homem: a viagem e o caminho (GALÁN, 2002). As descobertas de novos caminhos, de novos mundos e de um novo homem são as escolas da sabedoria. O próprio Montaigne, em seus ensaios, diz não haver melhor escola que os caminhos de uma viagem, os quais podem instaurar uma nova atitude.

Galán (2002), além disso, salienta que o gesto característico do viajante assemelhase intensamente do processo reflexivo e ensaístico. $\mathrm{Na}$ verdade, a viagem seria apenas uma metáfora para representar experiências que nos permitimos conhecer. Assim seria a essência do ensaio, deixar conhecer, exteriorizar uma reflexão pessoal, aventurar-se na ação de pensar, no ensinamento experimental e único. "Experimentar significa agora, não só provar, senão colocar-se a prova, isto é, ensaiar-se" (GALÁN, 2002, p. 9, tradução nossa). Era preciso ousar. Era uma civilização ousada, como o próprio Camões descreve em Os Lusíadas: "Ó gente ousada, mais que quantas / No mundo cometeram grande cousas".

O verbo ousar caracteriza, com precisão, todo o ímpeto revolucionário do 'homem moderno'; este, desligando-se dos laços medievais, filhos da tradição e da autoridade, ousa enveredar, solitário, por novos caminhos, numa aventura sem fim a que o imprevisível e o perigo dão doloroso gosto. Serão ousadia a Reforma, ousadia a ressurreição literária da antiguidade pagã, ousadia o heliocentrismo, ousadia o desterro do peripato, ousadia a físicomatemática, ousadia o experimentalismo crítico da 'nuova scienza', ousadia o realismo político, ousadia a consagração teológica da usura, etc. (LIMA, 1964, p. 18).

\footnotetext{
4 “Experimentar significa ahora, no solo probar, sino ponerse a prueba, esto es, ensayar-se".
} 
A produção artístico-cultural também se vê influenciada pelas “expansões", e busca produzir algo novo, mesmo que para isso se sustente nos exemplos da tradição clássica. É preciso pensar, produzir algo pessoal e não um eco das produções antigas. É importante ressaltar que a produção montaigniana não é uma cópia dos pensamentos clássicos, mas um encontro, uma convergência espontânea de opiniões.

Montaigne não imita os antigos: o que ele realiza é adaptar perante a vida uma atitude mental análoga à dos clássicos: analisar 'd'après Le nu', 'd'après la nature'. Faz como eles fizeram, mas o seu juízo é original, quer dizer, arranca da interioridade do eu como origem (LIMA, 1964, p. 76).

É a partir do Renascimento que Martínez (1964) considera que o ensaio começa a se configurar. O pesquisador acredita que, com a denominação feita por Montaigne, a palavra ensaio, inserida em um novo contexto, passou a cristalizar um novo paradigma, por conseguinte, uma nova "produção" discursiva. De modo mais específico, Cruz (1997, p. 51) confia que o ensaio surge precisamente no final do século XVI, enraizado à prosa argumentativa de caráter doutrinal, mas metamorfoseando tratamentos de alguns dos princípios comuns do gênero argumentativo. A procura por um pensamento que se traduza em arte.

Com isso se fará possível o despreconceito estabelecido na mais estreita coabitação de discurso ideológico e discurso artístico e, consequentemente, a relativa liberdade (em sentido que a este ponto pudera dar-lhe Hegel) caracterizadora do modo representativo e de linguagem do gênero do Ensaio (HARO, 1992, p. 116, tradução nossa). ${ }^{5}$

Haro (1992), inclusive, defende a tese de que o ensaio é fruto da modernidade, constituindo-se como um gênero naturalizado progressivamente pela cultura moderna, desde sua origem. Para o estudioso, a contemporaneidade do ensaio funda-se na "verdadeira liberdade de juízo por cima das prescrições da velha ordem cultural recebida do mundo antigo e desintegrada pela arte e pelo pensamento modernos" (HARO, 1992, p. 119).

Não obstante discussões reinem entre teóricos quanto à origem do ensaio, intricando a definição plena de sua trajetória, Cruz (1997) afirma que os ensaios não sugiram na Antiguidade, sendo fruto da modernidade. ${ }^{6}$ Afinal, Montaigne não acha na carta, na epístola,

\footnotetext{
5 “Con ello se hará posible el desprejuiciado establecimiento de la más estrecha cohabitación de discurso ideológico y discurso artístico y, consiguientemente, la relativa libertad (em sentido que a este punto pudiera darle Hegel) caracterizadora del modo representativo y de lenguaje del género del Ensayo.

${ }^{6}$ É importante resgatar o conceito de moderno dentro da perspectiva histórica para que não seja confundido com o Modernismo, pertencente às divisões das escolas literárias. Chama-se de Idade Moderna o período compreendido entre os séculos XV e XVIII, período de transição do mundo medieval feudal para o mundo capitalista burguês. Do século XIX em diante, a história denomina Idade Contemporânea.
} 
no diálogo, no tratado, nos gêneros medievais uma forma de dizer, de expor. Cria, a partir delas, uma nova "forma", nasce o ensaio. Como postula Todorov (1980, p. 46), "Um novo gênero é sempre a transformação de um ou de vários gêneros antigos: por inversão, por deslocamento, por combinação".

Isso posto, o ensaio já nasce como fruto da modernidade, tanto da palavra quanto do conceito. "Montaigne, ao empregar o termo pela primeira vez no domínio literário, reflecte com nitidez e força o individualismo e o dinamismo específicos do Renascimento europeu" (LIMA, 1694, p. 58). Vale ressaltar que, após os Ensaios de Montaigne, sucederam-se ensaios sobre filosofia, política, geometria, física, química, histórica, botânica, fisiologia, economia, arte, agronomia, metalurgia, entre outros, o que nos permite pontuar que o gênero ensaio, de fato, corporifica-se com os Essais de Michel de Montaigne.

Apesar de nascer em território francês, no século XVI, o ensaio expandiu-se nos séculos XVII e XVIII entre escritores anglo-saxônicos. Devido ao número de simpatizantes do gênero e sua difusão pelos países europeus e em outros continentes, em 1711, o gênero ganha a primeira revista dedicada inteiramente ao ensaio, The Spectator (MOISÉS, 2007). $\mathrm{E}$, ao mesmo tempo, dissemina-se pela Inglaterra.

Em território italiano, o cortejo forma-se especialmente através de Alfieri e Foscolo. $\mathrm{Na}$ Espanha, tardiamente o ensaio impetra em meio ao discurso, a epístola ou carta, a oração, entre outros gêneros. Posteriormente, renomados nomes almejaram esforços e o ensaio encontra "o clima ideal para desenvolver-se e alcançar altos níveis, mercê do aparecimento de figuras de porte europeu e internacional [...] mais recentemente, é considerável o número de cultores espanhóis do ensaio" (MOISÉS, 2007, p. 72-73).

A sociedade americana solidifica e propaga o gênero no século XVIII, devido aos pioneiros Benjamin Franklin, Thomas Paine e outros; no século seguinte, com Washington Irving; e, finalmente, pelo mais influente ensaísta norte-americano, Emerson, seguido por H. D. Thoreau, Oliver Wendell Holmes, James Russell Lowell, H. L. Mencken, George Santayanna e vários outros do século passado e do atual (MOISÉS, 2007).

Em Portugal, a antiga metrópole brasileira já esboçava o gênero na Idade Média, através de D. Duarte (O Leal Conselheiro). Todavia, no século XVIII adquire contornos mais complexos através de Verney, Antônio Nunes Ribeiro Sanches, Cavaleiro de Oliveira e Matias Aires. Na primeira metade do século XIX, Herculano se destaca pelos ensaios repletos de erudição histórica, acompanhado por Antero - popular pela rigidez da análise e por um filosofismo utópico de legítimo ensaísta. Quanto ao ensaísmo lusitano no século passado, Moisés (2007) pontua que o ensaio português vivera seu apogeu, tendo como ensaísta peculiar Antonio Sergio, o qual se sobressaía pela consistente propensão ao gênero.

\footnotetext{
${ }^{7}$ Mais adiante explicaremos a ênfase dada a palavra sobre. Por ora, ressaltamos apenas que há ensaios de e ensaios sobre.
} 
No Brasil, de acordo com Moisés (2007), a trajetória do ensaio inicia-se na época do descobrimento pelos portugueses, tendo como primeiro texto representativo do gênero a carta de Pero Vaz de Caminha, seguida das "observações de viajantes missionários e colonos a respeito da terra inculta e primitiva: Diálogos das grandezas do Brasil (1618), atribuídos a Ambrósio Fernandes Brandão; Cultura e Opulência do Brasil (1711), de Antonil” (MOISÉS, 2007, p. 74).

Apesar de insistirmos em traçar os caminhos do ensaio em território verde e amarelo, Guerini (2000), Portella (2000) e Moisés (2007) lembram que se trata de desvendar caminhos incompletos, obscuros. E, conforme pontua Portella (2000), qual ensaio? De modo geral, temos procurado apresentar um esboço representativo da trajetória da palavra ensaio até sua configuração como gênero discursivo. Nesse sentido, vale relembrar, apesar de nosso foco ser o ensaio literário, que até o momento traçamos a agitação do ensaio pelo Brasil e pelo mundo.

Corroborando Portella (2000), Antônio Candido (1980) considera a fase do modernismo como o período mais representativo do ensaio em território nacional, sobressaindo-se no momento devido à inquietação dos modernistas em procurar interpretar o Brasil. Para o reconhecido crítico literário, "é característico dessa geração o fato de toda ela tender para o ensaio. Desde a crônica polêmica [...] até o longo ensaio histórico e sociológico, que incorporou o movimento ao pensamento nacional" (CANDIDO, 1980, p. 123).

A busca pela decodificação do país tropical, contudo, já se esboçava entre os pré-modernistas. Nos períodos em questão, o objetivo era compreender o Brasil a partir da escolha de temas e problemas que fossem comuns, visto que no período modernista, "foram modificados, ou melhor, ampliados os recursos à disposição para pesquisas, propiciando uma maior liberdade textual, um sentido mais gregário dos intelectuais e a incorporação de novos cânones" (GAIO, 2004, p. 17).

As diversas manifestações do ensaio de formas díspares, que não mais como a de sua concepção, refletem a evolução natural dos enunciados, os quais buscam adaptar-se aos contextos históricos. Rodríguez Ávila (2007), a esse respeito, acrescenta que não se pode pensar que um gênero possa manter-se puro por séculos e séculos. Por isso, segundo a pesquisadora, existem diversas propostas de tipologia do ensaio.

Pontuadas algumas questões quanto ao processo de criação e propagação do gênero ensaio, na seção seguinte delineamos os caminhos de nossa análise.

\section{Metodologia e Constituição do Corpus}

As etapas de estudo do gênero ensaio produzido para o campo literário determinaram três momentos: i) investigação de obras que se intitulassem ensaio(s) e/ou abordassem enunciado-ensaio; ii) diagnóstico do material; iii) seleção e análise de textos representativos do gênero. 
No primeiro momento, percorremos bibliotecas, livrarias e, principalmente, sebos físico e virtuais. Nossa forma de busca consistiu na palavra ensaio. Todas as vezes que nos deparávamos com o vocábulo, filtrávamos apenas as obras que pudessem ter relação com nosso objeto de estudo, ignorando, por exemplo, títulos/subtítulos ou qualquer referência ao vocábulo ensaio(s) relacionado a outros campos, já que encontramos ensaios sobre temáticas filosóficas, históricas, psicológicas, do direito, da medicina, entre outros. Mesmo assim, ainda investigamos a possível relação com o contexto literário.

A palavra ensaio levou-nos a obras que apresentam coletâneas do gênero, mas que não têm o termo em seu título, por exemplo, Crivo de Papel, de Benedito Nunes, que, em sua apresentação, invoca o vocábulo: "reúne quinze dos ensaios mais recentes"; ou Filosofia Mínima, de Luís Augusto Fischer, que também descreve o ensaio como uma forma enunciativa presente na coletânea.

De início, todavia, confessamos que bastava ter o termo ensaio como título, subtítulo ou referência aos textos apresentados para selecionarmos a obra. Ao poucos, percebemos que somente isso não bastava, visto encontrarmos obras intituladas ensaio que não apresentavam ao menos um exemplo do gênero, o que nos levou a constatar que o termo costuma ser empregado com distintas significações. Por essa razão, antes de chegarmos ao enunciado, passamos a verificar se o autor, através de sua biografia, também era considerado um ensaísta. Dessa forma, chegamos a nove obras.

Muitos ensaios enveredam-se pela reflexão de obras, autores, escolas literárias e estilos. Ressaltamos, todavia, que as obras, por vezes, abordavam tanto ensaios literários da expressão subjetiva quanto ensaios literários da expressão crítica. ${ }^{8}$

Cinco autores foram significativos em nossas análises: Paulo Leminski, Ensaios e Anseios Cripticos; Augusto Meyer, A Forma Secreta, No Tempo da Flor e Augusto Meyer: ensaios escolbidos; Luís Augusto Fischer, Filosofia Minima, Para Fazer Diferença: ensaios e Crivo de Papel; Benedito Nunes, O Dorso do Tigre; e José Geraldo, Ensaios Literários. Ao todo, sopesamos as características de dezessete ensaios dos aludidos escritores, os quais foram escolhidos de forma aleatória, contudo sempre tendíamos para aqueles cujo título nos atraísse, embora selecionando a produção de ensaios da expressão subjetiva. Os ensaios foram estudados com base nos critérios de análise dos gêneros discursivos de Bakhtin (2003): contexto de produção; conteúdo temático; construção composicional e marcas linguístico-enunciativas. Com o levantamento das características a partir dos critérios bakhtinianos, procuramos responder "O que é um ensaio e como se constitui como gênero discursivo?", pergunta de nossa pesquisa e, assim, atender ao nosso objetivo de categorizar o gênero ensaio literário.

Enfim, o que é um ensaio literário? Na seção seguinte, apresentamos um levantamento das características mais estáveis do gênero, a essência que permite diferenciá-lo de outros gêneros e, também, algumas razões para considerá-lo um texto literário.

${ }^{8}$ Discutiremos mais a respeito na próxima seção. 


\section{O Gênero Discursivo Ensaio na Esfera Literária}

Os ensaios, de modo generalizado, propagam uma visão reflexiva. Sua essência é de base crítica, organizada especialmente em prosa. Como o ensaísta procura ser breve, sua extensão é considerada curta. Para a pesquisadora Maria Elena Arenas Cruz (1997, p. 17, tradução nossa), "sua liberdade composicional e aparente indeterminação formal tem condicionado sua fama de inclassificável “. Muitos pesquisadores e estudiosos classificam a essência do ensaio através da etimologia da palavra, construindo suas definições como gênero caracterizado como esboço, tentativa, rascunho, projeto não finalizado, entre outros.

Na esfera literária, o ensaio é marcado pela expressividade. ${ }^{9}$ Trabalhar artisticamente a palavra exige que o interlocutor se torne um cúmplice do ensaísta, instigando-o a interagir ativamente e a não se limitar a ser mero receptor. Tal cumplicidade faz com que o enunciatário aceite o discurso do escritor, não intervindo em sua criação linguística, nascida em uma esfera e organizada a partir de um gênero que lhe dão liberdade de criação.

No caso do texto ensaístico que merece ser chamado literário, os recursos expressivos seguem cumprindo esta função estética ou de desautomatização conotativa que atrai a atenção do destinatário sobre o próprio texto. Sem embargo, dado que no ensaio a criação engenhosa está fundida com o raciocínio especulativo e a vocação persuasiva, a função estética dos recursos expressivos da linguagem se amalgama a miúdo com a função argumentativa dos mesmos. Desta maneira, a expressividade do texto ensaístico é, além de uma fonte de prazer, uma fonte de conhecimento e um fator de persuasão (CRUZ, 1997 , p. 360, tradução nossa). ${ }^{10}$

Duas são as formas de manifestação do ensaio no domínio em tela: a primeira volta-se para a produção montaigniana, através da qual o ensaísta analisa um determinado assunto, produzindo sua tese, nas palavras de Eulálio (1992, p. 67) um enunciado-ensaio "de idéias gerais, concebido num teor de prosa artística". A segunda corporificou-se ao longo dos anos, foi hibridizando-se com o tempo e sofreu transformações que alargaram dimensões, contextos, finalidades e temas de gênero. Neste caso, o ensaio literário também se manifesta como crítica literária, em que o autor formula sua apreciação a respeito de uma

\footnotetext{
${ }^{9}$ Entendemos a expressividade como um conjunto de fenômenos elocutivos e dispositivos que tornam o texto mais atrativo ao leitor/ouvinte.

10 "En el caso del texto ensayístico que merece ser llamado literario, los recursos expresivos siguen cumpliendo esta función estética o de desautomatización connotativa que atrae la atención del destinatario sobre el propio texto. Sin embargo, dado que en el ensayo la creación ingeniosa está fundida con el razonamiento especulativo y la vocación persuasiva, la función estética de los recursos expresivos del lenguaje se amalgama a menudo con a la función argumentativa de los mismos. De esta manera, la expresividad del texto ensayístico es, la vez que una fuente de placer, una fuente de conocimiento y un factor de la persuasión".
} 
obra (livro(s); poema(s); autor(es); conjunto de obras; movimento artístico e literário; obras artísticas, como pintura, músicas, esculturas; enfim, sobre a arte em geral). Trata-se de um ensaio de "fato literário específico", conforme pontua Eulálio (1992, p. 67). De qualquer modo, o ensaio é pura reflexão. Ao primeiro ensaio, denominaremos ensaio literário da expressão subjetiva; enquanto chamaremos de ensaio literário da expressão crítica ao segundo modelo.

As produções nacionais sob o título de ensaio ou então rotuladas como tal, de modo amplo, abordam a expressão crítica. São textos que se direcionam para julgamentos literários. Nas palavras de Eulálio (1992, p. 12), o ensaio literário crítico consiste em uma "discussão estética do fato literário, sob a forma de estudos, análises, notícias, resenhas, recensões". É o caso, por exemplo, do ensaio literário Um Brasileiro Contra a Paisagem, de Moysés Vellinho, em que o ensaísta analisa vida e obra de Machado de Assis, tecendo julgamentos quanto aos motivos que tivera Machado para abordar negativamente alguns temas, o contexto social, a subjetiva vida machadiana, como ilustra o trecho a seguir:

Não sejamos por demais categóricos na afirmação de que a obra de Machado de Assis é resultante de condições exclusivamente subjetivas, para não dizermos patológicas... Os fatores externos são, via de regra, tão necessariamente presentes a toda a criação do espírito, que, se em relação a uma determinada obra eles se retraem ou neutralizam, há que considerar tal circunstância, pela sua própria obra. É certo que os livros de Machado de Assis - os da última fase mergulham suas fundas raízes na alma solitária e amargurada do grande escritor. Sem maior relevo externo, como que fechada a quaisquer transigências como as modas do tempo, a obra do criador de Quincas Borba lembra aquelas árvores angustiadas do deserto nordestino, que crescem tragicamente para baixo, metendo-se terra adentro em busca da umidade que a atmosfera não tem para lhes dar. A linfa que circula nas suas páginas disfarçadamente frias vem de muito fundo, trazendo à tona o ressaibo de todos os venenos que poluem as vertentes obscuras do espírito. Quem viveu condenado a debater-se dentro de si mesmo, na obsidente tortura de ocultar-se aos próprios olhos, só poderia ter realizado uma obra enraizadamente pessoal. Ninguém ousaria contestá-lo sem incorrer num paradoxo gratuito em face de uma questão que é sem dúvida a mais séria, a mais relevante da literatura brasileira (VELLINHO, 2001, p. 47-48).

A expressão crítica literária emoldurada pelos contornos do gênero ensaio, em especial, concentra-se na reflexão pessoal, no julgamento do ensaísta a respeito de vida/ obra/estilo de um escritor. Todavia, a mesma crítica literária ainda avança quando busca, por vezes, analisar como um tema específico é abordado por diversos autores, por escritores de um período literário, correlacionando o tema, em alguns casos, a conceitos históricos e filosóficos. Para ilustrar a referida abordagem ensaística produzida por escritores brasileiros, selecionamos trechos do ensaio O Carpe Diem na Poesia Brasileira, de José Geraldo (2005, p. 140-141):

Não são recentes as cogitações que tenho feito a propósito da insistência com que a temática do carpe diem aparece na literatura brasileira, mesmo se a considerarmos restrita a textos de autores consagrados. [...] Em nossa cultura, a expressão latina carpe diem quam 
minimum credula postero (aproveita o dia sem confiar no dia de amanhã) se prende ao conselho dirigido por Horário aos epicuristas, no sentido de que o tempo não deve ser desperdiçado. [...] Já afirmei, ter verificado a insistência com que a temática de que estou tratando se apresenta em nossa poesia, o que implica o seu registro na sucessão cronológica de nossos poetas, e nisso se apóia meu interesse pelo assunto. Não se trata de um caso singular, pois é na perenidade de determinados temas que nos podemos apoiar para dizer que hoje, como nos passados séculos, o homem manifesta amor, indiferença, ódio, solidariedade, aspiração, interesse, despeito, calúnia, tédio, ansiedade, coisas que nada têm a ver com o estado de progresso ou com adiantamento tecnológico das diferentes épocas, residindo nesta observação um dos argumentos em que se apóia a afirmativa de que a arte é atemporal. [...] A conclusão é que o carpe diem na relação homem / mulher está intimamente ligado à fugacidade do tempo, ao aproveitamento do agora, a partir de que ninguém conhece as incertezas do amanhã...

No texto-enunciado em questão, o ensaísta analisa poemas seletos que se situam entre o Barroco e o Pré-Modernismo - período que o próprio autor delimita no início do ensaio - para confirmar sua tese de que o carpe diem, na poesia do período arrolado, no que tange ao relacionamento entre homem e mulher, configura-se como "fugacidade do tempo".

Relembramos que não temos por objetivo analisar incansavelmente cada produção no que diz respeito às formas como o ensaio literário pode se manifestar; nosso fulcro incide em ilustrar a maneira como a abordagem ocorre nos enunciados concretos dos ensaios literários, ao levarmos em consideração os ensaios que analisamos.

O ensaio literário também pode ser produzido "à moda Montaigne”. Nesse caso, ensaios de expressão subjetiva, através dos quais o ensaísta reflete sobre um assunto amplo de modo subjetivo, não se limitando a um autor, conjunto de obras, período literário, ou mesmo a um assunto presente na literatura. Isso não significa que o escritor não possa recorrer a obras literárias e a escritores para corroborar o pensamento que procura sustentar. O ensaio literário como expressão subjetiva discute, analisa, pondera, reflete o seu objeto de estudo. Epistola a Porfírio, de Augusto Meyer, ${ }^{11}$ foi o ensaio selecionado para demonstrar o referido caso. $\mathrm{O}$ trecho que segue é o primeiro parágrafo do ensaio:

O melhor, nestas coisas de escrevinhação e aprendizado, é começar pela modéstia, relembrando a observação de Charles Bailly: 'Na verdade, a pessoa mais culta conhece quando muito uma terça parte das palavras catalogadas nos dicionários, e longe estão os dicionários de um registro completo dos vocábulos de uma língua’. A leitura dos dicionários serve ao menos para mostrar que você, deletrado amigo, às voltas no momento com uma cabeça-de-ponte para os lados do russo e já de namoro com o árabe, não conhece ainda essa estranha terra natal chamada língua portuguesa (MEYER, 2009, p. 18).

\footnotetext{
${ }^{11}$ Augusto Meyer, segundo Alberto da Costa e Silva, foi um "dos maiores ensaístas que jamais tivemos". Foi mestre do ensaio breve. Conciso abordava temas com extrema profundidade, pois sabia fundir, em poucas palavras e páginas, a essência harmoniosa do tema.
} 
As características elencadas até o momento e os recortes feitos de ensaios como expressão subjetiva permitem-nos a seguinte conclusão: o ensaio tem por finalidade desvendar o objeto de análise, seja um sentimento, um fato, pessoas, gêneros, assuntos, obras, períodos literários ou artísticos, autores, enfim, coisas do dia a dia do ensaísta ou que se relacionam à arte e à cultura.

Os textos-enunciado do gênero ensaio da esfera literária apresentam duas dimensões: a) lógica; e b) estética. A dimensão lógica do gênero consiste na análise pessoal de um único tema e na consolidação das ideias. A dimensão estética é a perspectiva responsável pelo domínio do idioma e pelo uso de recursos expressivos. Em outras palavras, divulga artisticamente a tese alcançada.

Neste estudo, concentramo-nos no ensaio literário como expressão subjetiva. Para o análise, conforme já mencionado, observamos aspectos discursivos, baseando-nos nos conceitos bakhtinianos quanto a: i) conteúdo temático; organização composicional e estilo, ${ }^{12}$ vinculados ao contexto de produção; e ii) aspectos expressivos.

No primeiro tópico - aspectos discursivos - apresentamos características do gênero no tocante a elementos que perpassam a enunciação e determinam a escolha do enunciador. Dessa forma, pautando-nos em Bakhtin (2003), debatemos sobre a finalidade do gênero, seu contexto de produção, organização composicional, sobre o ensaísta e seu papel social, seu interlocutor, a escolha temática - visto estar relacionada ao contexto sócio-histórico em que o enunciado é produzido e, por isso, determinante das escolhas feitas pelo enunciador.

Haro (1992) idealiza o ensaio como livre discurso reflexivo, por se configurar a partir de um discernimento estruturado à margem de teorias científicas ou convenções. Eis a finalidade/objetivo do gênero: apresentar uma reflexão pessoal, independentemente das veredas comunicativas que venha a percorrer. "O ensaísta, prova e põe à prova, em uma palavra, experimenta-se, vivendo em si e por si mesmo o que dá de si a condição humana" (GALÁN, 2002, p. 6-7, tradução nossa). ${ }^{13}$ A vontade que move o ensaísta recai sobre desvendar o objeto de análise. Afinal, o discurso ensaístico "nasce com uma clara vontade de comunicabilidade, de chegar ao maior número de pessoas possíveis, o qual leva seu autor a acomodar a expressão das capacidades intelectuais de um público que imagina culto, porém não especializado" (CRUZ, 1997, p. 357, tradução nossa). ${ }^{14}$

Sob o prisma delineado, o ensaísta escreve para um tipo de interlocutor que não requer tecnicismo, nem uma linguagem científica particularizada, por esse motivo, impõe certas restrições quanto ao assunto em virtude de seu enunciatário.

\footnotetext{
${ }^{12}$ Ao abordarmos o estilo, discutiremos também a expressividade presente nos textos-enunciados do gênero ensaio na esfera literária.

13 "El ensayista, prueba y se pone a prueba, en una palabra, se experimenta, viviendo en si y por si mismo lo que da de si la condición humana" (GALÁN, 2002, p. 6-7).

14 "El discurso ensayístico nace con una clara voluntad de comunicabilidad, de llegar al mayor número de personas posible, lo cual lleva a su autor a acomodar la expresión a las capacidades intelectuales de un público que imagina culto pero no especializado".
} 
O ensaio se dirige 'aos cultos em geral' seja qual for a especialidade de cada um, a leitura de um ensaio não requer nenhuma especialização. À generalidade dos cultos corresponde a 'generalidade dos temas', que pode tratar-se em estilo de ensaio, e a generalidade em estilo de tratamento. O ensaísta pode saber, sobre o tema eleito, muito mais do que é justo dizer no ensaio. A obrigação de dar-se a entender implica somente um cuidado com a clareza formal, sem a eliminação de todos aqueles aspectos técnicos, se houver, cuja compreensão implicaria no leitor uma preparação especializada (CRUZ, 1997, p. 358, tradução nossa). ${ }^{15}$

Não obstante sua temática seja extremamente heterogênea, o ensaísta afunila seu repertório temático em função do enunciatário que projeta virtualmente. Ademais, o campo social no qual se insere, adicionado da projeção do outro (leitor/ouvinte) e de seu papel social no momento da enunciação, restringe os assuntos a serem ensaiados.

Por isso, a arte ensaística é considerada um gênero literário que trata de um quadro de referências uni ou multidimensional com variadas possibilidades de entrelaçamento de diversas visões intelectuais. Temas que convidam à liberdade de interpretação porque apresentam muitos planos de leituras, justapondo opiniões próprias e alheias em graus variáveis de percepção e compreensão (LAGO JR, 1990, p. 7).

O ensaio é um livre comentário estético, proclamado a partir de um juízo crítico ínfimo de prosa literária desenvolvida. Talvez, por essa definição, Eulálio (1992, p. 12) classifique a esfera do gênero como sendo "belas-letras". Nesse contexto, segundo Moisés (2007, p. 89), o ensaísta é

um problematizador, na medida em que ergue o problema onde o conformismo havia instalado seu reino de axiomas, postulados e dogmas, ou divisa problemas onde parece não existir senão o vago anseio do futuro: o mundo como espaço problemático, o ser como ente problemático, a cultura como epifenômeno problemático, eis as coordenadas que norteiam o ensaísta.

Ao descobrir dentro de si mesmo, o ensaiador de palavras emprega, assim como o criador do gênero - Montaigne -, ao estilo causerie, uma espécie de bate-papo, de conversa, uma vez que o referido estilo consiste em um "processo instrumental mais eficiente, íntimo, directo, penetrante, de comunicação entre um eu e outro eu. [...] é um escrever onde se impregnam o calor,

\footnotetext{
15 “El ensayo se dirige 'a la generalidad de los cultos'. Sea cual sea la especialidad de cada uno, la lectura de un ensayo no requiere en ninguno la especialización. A la generalidad de los cultos corresponde la 'generalidad de los temas' que pueden tratarse en el estilo de ensayo y la generalidad em el estilo mismo del tratamiento. El ensayista puede saber, sobre el tema elegido, mucho más de lo que es justo decir em el ensayo. La obligación de darse a entender no implica solamente un cuidado de la claridad formal, sino la eliminación de todos aquellos aspectos técnicos, si los hubiere, cuya comprensión implicaría en el lector una preparación especializada."
} 
o sopro, a cor e o timbre de uma voz" (LIMA, 1964, p. 54). Desse modo, o "eu" é presença marcante no ensaio, um "eu" que escreve e que procura refletir um "eu” que próprio ensaísta desconhece.

Linguagem para os ouvidos, como que se dirige a um interlocutor e não a um leitor. De onde a propriedade gramatical e estilística estar a serviço do diálogo, nunca arvorar-se em fim de si mesma. O ensaio há de guardar um núcleo de conversa se não quiser mergulhar na esterilidade conseqüente à esterilização da linguagem: escrever como quem fala, elevadamente, de assuntos vários, como quem tivesse o dom da eloqüência natural e singela, como se o escritor não perdesse de vista o homem que se dirige a seus semelhantes por meio do diálogo (MOISÉS, 2007, p. 96).

Nessa perspectiva, o ensaísta exterioriza sua subjetividade no ensaio, desejando que o enunciatário ao menos compreenda seu modo de pensar como uma possibilidade de se ver o objeto em análise, daí a preferência por temas da atualidade. Como o autor se projeta no enunciado, é recorrente o emprego da primeira pessoa do discurso. Em contrapartida, o "eu" que interage com ensaísta através do enunciado concreto busca encontrar novas perspectivas, novas formas de aproximar-se de um tema. É um participante ativo. Isso posto, o ensaio é um enunciado subjetivo. Sua subjetividade versa em apoiar-se na imaginação, na emotividade, "entendida não como passionalidade dogmática e polêmica, mas como a disposição anímica para aderir empaticamente aos assuntos [...] o ensaio reclama emotividade" (MOISÉS 2007, p. 88).

Expressivamente, o ensaio literário, como "conjectura especulativa e interpretativa" (HARO, 1992, p. 21), traduz-se em uma linguagem artesanal, dialógica e artística. Desse modo, recorrendo outra vez aos estudos de Haro (1992, p. 117), o ensaio reflete uma "artistização" verbal e exposição reflexiva, no qual nos deparamos com a vivência individual, refletida a partir de uma abordagem universal, em que se predomina uma autonomia crítica. Em outras palavras, a vivência experimental da universalidade, através de uma autonomia mental. A linguagem ensaística, de modo geral, traduz-se metaforicamente. Por tal razão, o estilo do ensaio é pura criação,

visto que nutrido de seiva sempre nova, e é já por esse ângulo - beleza e forma - que o ensaio se inscreve no perímetro literário: aqui, a linguagem que se recria perpetuamente, faz apelo à imaginação, ao esforço do 'eu' para dizer-se e comunicar-se ao leitor, por meio do emprego regular da metáfora (MOISÉS, 2007, p. 96).

Linguisticamente, as orações constituintes do ensaio literário são muito organizadas. Suas ideias vão sendo engenhosamente traçadas, articuladas e comprovadas, dando e confirmando a essência argumentativa. Haro (1992) salienta que se torna necessário reconhecer as harmoniosas frases que compõem o ensaio, as quais são as engrenagens para o conjunto da obra. As frases, nos textos-enunciados do gênero em questão, são formuladas de modo atraente, o que aproxima a prosa ensaísta da poesia.

No discurso ensaístico-literário, a opinião pessoal-experimental do ensaísta pode ser corroborada pelo discurso de autoridade. De acordo com Lima (1964, p. 74), "o processo 
de leitura para maior compreensão do assunto, não significa que o lido será repetido, mas assim como a abelha fabrica mel a partir do néctar de várias flores, assim o ensaísta produz sua crítica". Ademais, o juízo crítico do gênero em pauta, levado a efeito por um caráter dialogal, persuasivo, incorpora um "tom divagante, sinuoso e familiar de confissão ou confidência, de calor natural e vida subjectiva" (LIMA, 1964, p. 82). Contudo, o espírito que analisa é breve, "o ensaísta é breve porque antípoda do nefelibata, breve porque realista" (MOISÉS, 2007, p. 82). A brevidade do ensaio é qualidade de veracidade ou adaptação à realidade.

O ensaio pede-se breve, a brevidade própria de uma estrutura na qual e por meio da qual a mente intui fragmentos da realidade e satisfaz-se com a sua captação: a brevidade equivale a uma tomada fotográfica, que se basta na apreensão das minúcias e recusa panoramas, ou porque transbordem das fronteiras em que se movimenta a câmara (do ensaísta), ou porque a análise importa mais do que a síntese. $O$ ensaio é o assalto à realidade entendida como soma infinita de pormenores, sem curar de sua totalidade; a inteligência que a escolhe como instrumento de apreensão gnoseológica deseja-se breve para ser inteira e deseja breve o objeto de conbecimento a fim de capturá-lo em sua flagrância e imediatez. (MOISÉS, 2007, p. 82, grifos nossos).

Além das considerações expostas, o ensaio insere-se no domínio da discussão, e por isso se apoia na argumentação para refletir um pensamento crítico. De tal modo, o ensaísta expõe juízos de valor sobre um objeto de estudo, especificando seu posicionamento através de exemplos, evidências e contrastes. Demonstra explicativamente, as causas ou as razões de seu discernimento. O gênero, portanto, requer sustentação, refutação e/ou negociação.

Os textos-enunciados do gênero discursivo ensaio organizam-se, de forma geral, em prosa e são marcados pela brevidade. Não há, no enunciado ensaístico, o compromisso com provas, mas o desenvolvimento de um escrito racionalmente lógico, intuitivo, à procura de um saber original. O ensaísta redige buscando "na concretização verbal, em que medida é defensável o seu entendimento do problema em foco” (MOISÉS, 1982, p. 177).

Para saber se o pensamento que lhe habita a mente é original, estrutura o texto em que ele se mostra autêntico ou disparatado: escrevendo a pensar, ou pensando a escrever, o ensaísta só pode avaliar a ideia que lhe povoa a inteligência no próprio ato de escrever. Escreve para divisar melhor o que pensa e saber se pensa corretamente. Daí que o ensaio se constitua num exercício ou manifestação de humildade, e faça da brevidade e da clareza de estilo os seus esteios máximos: o ensaísta conhece por experiência as limitações do saber humano e que os torneios frásicos absconsos, o vocabulário especioso e bizantino, os neologismos forçados, etc. não raro escondem o vazio intelectual (MOISÉS, 1982, p. 177).

Ao buscar tecer suas considerações, o ensaísta quer ser o mais claro e conciso possível, porque sabe que o melhor argumento é aquele que não requer muitas palavras, nem mesmo muitas explicações. Por isso, é também um mestre das palavras, pois as garimpa 
na medida certa, não se delonga, nem impetra discursos obscuros. As palavras, muitas vezes, são empregadas sem extrema erudição, são organizadas com harmonioso labor, formando um escrito belo, marcado pela delicadeza de um humilde discurso. Ser ensaísta é, acima de tudo, ser um “bom escritor”, conforme pontua Moisés (1982, p. 177).

Em meio às colocações já expostas, orientamo-nos a configurar as regularidades/ irregularidades que caracterizam os ensaios da esfera literária, a partir das análises feitas por nós, expostas no quadro em sequência:

\section{Quadro 1- Características do ensaio literário}

\section{ENSAIO LITERÁRIO}

\section{Contexto de produção e relação autor-leitor-texto}

\begin{tabular}{|l|l|}
\hline $\begin{array}{l}\text { Autor-enunciador } \\
\text { Provável } \\
\text { destinatário }\end{array}$ & É representado pela posição social do sujeito ensaísta. \\
\hline Meios de circulação & $\begin{array}{l}\text { Livros e alguns sítios da internet. Por vezes, pode circular em jornais e } \\
\text { revistas, mas costuma ser produzido para suportes de circulação mais } \\
\text { perenes. }\end{array}$ \\
\hline $\begin{array}{l}\text { Provável objetivo } \\
\text { da interação }\end{array}$ & $\begin{array}{l}\text { Apresentar uma reflexão pessoal a respeito de um assunto/uma ideia, } \\
\text { sob um viés artístico. }\end{array}$ \\
\hline Conteúdo temático &
\end{tabular}

Variável e avaliativa e interacionalmente construído.

\section{Construção Composicional e o estilo}

- Nível gráfico: disposição das palavras em prosa, de extensão moderada, com título criativo - para despertar o interesse do leitor; apresentação do assunto; desenvolvimento - argumentos, referências, exemplificações etc.; desfecho, parte em que o autor encerra sua reflexão sem a pretensão de esgotar o tema e apresentar respostas exatas, mas ratificar a conclusão a que chegou após exímia análise;

- Nível lexical: escolha lexical realizada pelo ensaísta, com preferência para uma linguagem não muito erudita;

- Nível sintático: preferência por períodos curtos; alterações sintáticas (ou figuras de sintaxe ou de construção);

- Nível semântico: figuras de linguagem, intertextualidade;

- Nível discursivo: em geral, emprega-se um tom conversacional; o ensaísta assume um viés didático, propedêutico e, às vezes, teórico; caráter de desafetação e serenidade; posicionamento crítico e reflexivo.

Fonte: Elaborado pela autora. 
Em síntese, o ensaio é um gênero literário em que a finalidade estética aparece entrelaçada ao processo reflexivo, no qual um não sacrifica o outro. Sua produção concentrase nas mãos de renomados literatos, que o organiza por meio de uma linguagem clara e acessível, pontuada brevemente, com circulação, comumente na esfera literária-cultural, ou, como considera Eulálio (1992), "belas-letras".

\section{Considerações Finais}

O trabalho com gêneros (discursivos ou textuais), na contemporaneidade, deve nortear as práticas de ensino e aprendizagem de língua portuguesa, consoante orientam documentos oficiais como os Parâmetros Curriculares Nacionais (BRASIL, 2007, 2008) e as Diretrizes Curriculares do Estado do Paraná (PARANÁ, 2008). Todavia, não obstante os gêneros estejam paulatinamente adentrando as salas de aulas, alguns, ou muitos, ainda requerem maiores delimitações a fim de possibilitar uma abordagem mais profícua em contexto escolar.

O ensaio é uma modalidade discursiva constantemente incompreendida e, ainda, não apresenta profundas noções teóricas, capazes de eliminar as distintas concepções que lhe são atribuídas. A desorientação ocorre não somente entre os corajosos escritores que se aventuram a escrevê-lo, mas também entre teóricos e críticos literários. Em 2012, a Folha de São Paulo, ao fazer a apresentação de um livro de ensaios, fez o seguinte comentário: "Entoados pela cumplicidade de uma conversa informal, os ensaios talvez sejam os melhores amigos de um escritor. O gênero literário ainda relativamente pouco exercitado no Brasil [...]".

Sob tal enfoque, motivados pela enigmática forma do ensaio, procuramos percorrer os caminhos que delineiam essa modalidade discursiva. Não obstante, embora neste trabalho apresentemos um estudo que nos levou a uma possibilidade de categorização para o ensaio literário, ressaltamos que os contornos delineados para o gênero são frutos do caminho percorrido em nossas pesquisas, leituras e análises. Talvez haja outras marcas, talvez existam outras informações relevantes, quem sabe outros aspectos importantes presentes em outros ensaios. Entretanto, cremos que o estudo empreendido permite delinear as características de um gênero considerado de difícil caracterização. De qualquer forma, fica uma proposta que pode ser complementada.

\section{REFERÊNCIAS}

ADORNO, T. W. O ensaio como forma. In: ADORNO, T. W. Notas de literatura. Tradução e apresentação de Jorge M. B. de Almeida. 2. reimp. São Paulo: Duas Cidades; Ed. 34, 2008. 
BAKHTIN, M. Estética da criação verbal. 4. ed. São Paulo: Martins Fontes, 2003.

BAKHTIN, M.; VOLOCHINOV, V. N. Marxismo e filosofia da linguagem. 11. ed. São Paulo: Hucitec, 2004.

BRASIL. Parâmetros Curriculares Nacionais: língua portuguesa: primeiro e segundo ciclos. Brasília: MEC; SEF, 2007.

BRASIL. Parâmetros Curriculares Nacionais: língua portuguesa: terceiro e quarto ciclos. Brasília: MEC; SEF, 2008.

CANDIDO, A. Literatura e sociedade: estudos de teoria e história literária. 6. ed. São Paulo: Nacional, 1980.

CRUZ, M. E. A. Hacia una teoría general del ensayo: construcción del texto ensayístico. Cuenca: Ediciones de la Universid de Castilla; La Manha, 1997.

EULALIO, A. O ensaio literário no Brasil. In: EULALIO, A.; WLADMAN, B.; DANTAS, L. (Org.). Escritos. Campinas: Editora da UNICAMP; São Paulo: Editora UNESP, 1992.

GAIO, A. M. Modernismo e ensaio histórico. São Paulo: Cortez, 2004.

GALÁN, P. C. El espíritu del ensayo. In: GALÁN, P. C. et al. El ensayo: entre la filosofía y la literatura. Granada: Comares, 2002. p. 1-32.

GERALDO, J. Ensaios literários. Brasília: Thesaurus, 2005.

GUAL, G. Ensayando el ensayo: Plutarco como precursor. Revista de Occidente, n. 116, p. 25-26, 1991.

GUERINI, A. A teoria do ensaio: reflexões sobre uma ausência. Anuário de Literatura 8 , p. 11-27, 2000.

HARO, P. A. de. Teoría Del ensayo. 2. ed. Madrid: Verbum, 1992.

LAGO JR., S. O ofício do ensaísta. Logos: Comunicação e Universidade, Rio de Janeiro, v. 1, n. 1, 1990 .

LEMINSKI, P. Ensaios e anseios crípticos. 2. ed. ampl. Campinas: Editora da Unicamp, 2012.

LIMA, S. Ensaio sobre a essência do ensaio. 2. ed. Coimbra: Armênio Amado, 1964.

MARTÍNEZ, G. B. Sobre el concepto de "ensayo". In: SIMPOSIO EL PADRE

FEIJOO Y SU SIGLO, 1964, Oviedo, Astúrias. Oviedo, Tomo 1, p. 89-112, 1966.

Disponível em: <https://bit.ly/2PmLRdM>. Acesso em: 23 maio 2013. 
MEYER, A. A forma secreta. 4. ed. Rio de Janeiro: Francisco Alves, 1965.

MEYER, A. Ensaios escolbidos. Seleção e prefácio de Alberto da Costa e Silva. 3. ed. Rio de Janeiro: José Olympio, 2009.

MOISÉS, M. O Ensaio. In: MOISÉS, M. A criação literária: Prosa II. 20. ed. São Paulo: Cultrix, 2007. p. 69-100.

MONTAIGNE, M. E. de. Ensaios. Tradução de Sérgio Milliet. 2. ed. São Paulo: Abril Cultural, 1980. (Coleção Os Pensadores).

PARANÁ. Secretaria de Estado da Educação. Diretrizes Curriculares da Educação BásicaLíngua Portuguesa. Curitiba: SEED; DEB, 2008.

PERFEITO, A. M. Concepções de linguagem, teorias subjacentes e ensino de Língua Portuguesa. In: Concep̧ões de linguagem e ensino de Lingua Portuguesa, Maringá, v. 1, n. 1, p. 2775, 2005. (Formação de Professores EAD, 18).

PORTELLA, E. M. O ensaio. 2000. (Conferência). Disponível em: $<$ https://bit.ly/2BiNRjk>. Acesso em: 27 out. 2013.

PROENÇA FILHO, D. Estilos de época na literatura: através de textos comentados. 9. ed. São Paulo: Ática, 1985.

RODRÍGUEZ ÁVILA, Y. del C.. El ensayo académico: algunos apuntes para su estudio. Sapiens: Revista Universitária de Investigación, Caracas, a. 8, n. 1, p. 147-159, jun. 2007. Disponível em: <https://bit.ly/2HVGp3s>. Acesso em: 09 abr. 2010.

ROJO, R. Gêneros do discurso e gêneros textuais: questões teóricas e aplicadas. In: MEURER, J. L.; BONINI, A.; MOTTA-ROTH, D. (Org.). Gêneros: teorias, métodos, debates. São Paulo: Parábola, 2005. p. 184-293.

SARAIVA, A.; LOPES, Ó. História da Literatura Portuguesa. 12. ed. Porto: Porto, 1997.

SOARES, A. Gêneros literários. 6. ed. São Paulo: Ática, 2006.

TODOROV, T. Os gêneros do discurso. Tradução de Elisa Angotti Kossovich. São Paulo: Martins Fontes, 1980.

VELLINHO, M. Ensaios literários Moysés Vellinho. Porto Alegre: Instituto Estadual do Livro; CORAG, 2001. (Organização de Carlos Alexandre Baumgarten). 